\title{
INFOGRAFIS SEBAGAI MEDIA ALTERNATIF DALAM PEMBELAJARAN SEJARAH BAGI SISWA SMA
}

\author{
Taufiq Harpan Aldila ${ }^{1}$, Akhmad Arif Musadad ${ }^{2}$, Susanto ${ }^{3}$ \\ ${ }^{1}$ Pascasarjana Universitas Sebelas Maret, \\ ${ }^{2}$ Progdi Pendidikan Sejarah FKIP Universitas Sebelas Maret, \\ ${ }^{3}$ Progdi Ilmu Sejarah Universitas Sebelas Maret \\ aldila911@gmail.com ${ }^{1}$, arif_mussadad_fkip@yahoo.co.id ${ }^{2}$, susantofibuns@staff.uns.ac.id ${ }^{3}$
}

\begin{abstract}
Abstrak
Nilai-nilai kepahlawanan merupakan representasi nilai sikap yang harusnya didapati siswa dalam pembelajaran sejarah. Konten buku paket sejarah di Sekolah belum memberikan porsi cukup guna pembahasan mengenai tokoh kepahlawanan. Kompleksitas dan monotonnya buku ajar sejarah memberi sumbangsih pada minimnya minat belajar siswa. Era digitalisasi visual setidaknya menjadi sebuah tantangan yang harus direspon demi mengembangkan konten pembelajaran yang inovatif. Konten pembelajaran sejarah merupakan salah satu ranah kognitif yang harus mampu diserap siswa secara maksimal, sehingga perlu adanya metode maupun media agar konten tersebut terserap secara maksimal. Metode yang digunakan dalam penelitian ini adalah metode pengembangan atau Research and Development dengan mengacu pada model perancangan ADDIE (Analyze, Design, Development, Implementation and Evaluation). Metode pengambilan data lapangan didapat dari hasil wawancara dan observasi pada analisis kebutuhan. Pre test dan post test digunakan untuk mendapatkan data prestasi belajar dan kesadaran sejarah siswa. Penilaian yang diberikan oleh para ahli dapat disimpulkan bahwa bahan ajar sejarah biografi pahlawan dinyatakan layak untuk diterapkan dalam pembelajaran sejarah, dan terdapat perbedaan tingkat kesadaran sejarah antara kelas yang tidak menggunakan bahan ajar biografi pahlawan sejarah berbasis infografis dengan yang menerapkannya.
\end{abstract}

Kata Kunci: bahan ajar, biografi, infografis, pahlawan

\begin{abstract}
Heroes values are the representation of attitude that students must acquire in learning history. The history book content in the school has not provided enough portion for the discussion about heroism. The complexity of history textbooks has an impact on students' decreased interest in learning. The era of visual digitalization is a challenge that must be responded to develop innovative learning content. Historical learning content is a cognitive domain that students must be able to receive optimally, so there is a need for methods and media to solve it. The method used in this research is the Research and Development method with reference to the ADDIE design model (Analyze, Design, Development, Implementation, and Evaluation). Needs analysis obtained by using interview and observation methods. Pretest and posttest were used to obtain data on student achievement and historical awareness. Conclusion The assessment given by experts that the historical teaching material of the hero biography is declared deserve to be applied in historical learning, and also there are differences in the level of historical awareness between classes that do not use teaching materials based on infographic historical heroes with those who apply them.
\end{abstract}

Keywords: biography, handout, heroism, infographic 


\section{PENDAHULUAN}

Menurut Wiraatmadja perlunya pengajaran sejarah sebagai persiapan pendewasaan generasi muda dalam menjawab aneka tantangan masa depannya. Tantangan pembelajaran sejarah di era modern adalah dengan terus bergerak maju mengikuti perkembangan zaman termasuk perkembangan teknologi dan media. Hadirnya modelmodel pembelajaran yang menyenangkan ternyata lebih bisa menarik minat belajar siswa (Wiraatmadja, 2002). Pada era dewasa ini pembelajaran dihadapkan pada pembelajaran berbasis digital bagaimana kemudian materi yang diajarkan dapat diakses kapanpun dan dimanapun. Media pembelajaran yang mengusung misi praktis dan ringkas lebih dipilih oleh siswa.

Perihal meningkatkan minat siswa tidak hanya pada ranah pengembangan media pembelajaran yang digunakan. Konten pembelajaran sejarah juga menjadi fokus yang harus dicermati. Dewasa ini bagaimana kemudian konten mampu dikembangkan sesuai dengan kebutuhan siswa. Kurikulum yang telah diterapkan oleh pemerintah adalah kurikulum 2013 yang kemudian mengedepankan pada pengembangan ranah sikap atau afektif. Konten bahan ajar ditujukan dan disusun sesuai dengan cita-cita bangsa. Melalui buku teks sejarah, peserta didik diharapkan dapat berpikir sejarah untuk menyelami masa lalu dan memahami konteks jamannya. Pemahaman sejarah ini dapat menjadi proses "memanusiakan" manusia. Sehingga dapat bertindak sebagaimana manusia seutuhnya yang berperasaan, arif, bijak, dan tentu menjadi penilaian serta pemikiran yang berwawasan jauh ke depan, teliti dan kritis menghadapi segala tantangan (Wawan Darmawan, 2016).

Permasalahan dalam pembelajaran sejarah di sekolah salah satunya terdapat pada unsur penunjang pemahaman yaitu buku teks. Hampir seluruh buku ajar, baik yang diterbitkan oleh swasta maupun pemerintah sebenarnya tidak layak untuk dijadikan referensi. Hampir seluruh penulis buku hanya membaca dokumen kurikulum secara harfiah dan tidak mampu memahami jiwa kurikulum dengan baik. Sebagian besar penulis buku juga tidak paham sejarah sebagi ilmu, historiografi, dan tertinggal sangat jauh dalam referensi mutahkir penulisan (Purwanto, 2006 ). Pada situasi ini yang seharusnya menjadi jembatan antara kebutuhan dan suplai materi adalah guru yang merupakan individu yang dekat dengan siswa.

Menurut Helius Syamsudin (Syamsuddin, 1998) kedudukan, fungsi dan peranan buku teks sejarah amat strategis karena menyangkut pembentukan aspek-aspek kognitif (intelektual) dan afektif (apresiasi, nilai-nilai) semua peserta didik dari setiap jenjang pendidikan. Sejarah nasional khususnya dianggap mempunyai nilai didaktif-edukatif bagi pembentukan jati diri bangsa dan pemersatu berdasarkan atas pengalaman kolektif bernegara dan berbangsa. Lebih lanjut ia menuliskan beberapa hal yang perlu diperhatikan oleh penyusun buku teks sejarah, yaitu (1) substansi faktualnya harus benar-benar dapat dipertanggungjawabkan secara akademis dan sedapat mungkin menggunakan sumber primer; (2) penafsiran atau penjelasannya harus logis, sistematis, serta memperhatikan visi atau kebijakan pendidikan dan atau politik yang berlaku secara nasional; (3) penyajian dan retorikanya harus sesuai jenjang usia siswa menurut teori 
psikologi perkembangan yang umum dikenal; (4) pengenalan konsep-konsep sejarah perlu menggunakan pendekatan "spiral", dimulai dari konsep sederhana menuju konsep yang lebih kompleks; (5) secara teknis. Pemaparan menurut Helius tersebut mencoba memberikan sebuah pandangan mengenai ideal sebuah bahan ajar dikembangkan. Meskipun kebaruan dan inovasi terus dikembangkan namun ideal pakem dari bahan ajar harus tetap dikedepankan. Pada hakikatnya keberterimaan materi sejarah kepada siswa tergantung pada dua aspek yang dirumuskan dari hasil wawancara kepada beberapa siswa di tempat penelitian.

Responden merupakan siswa kelas XI SMAN 2 Ungaran. Aspek pertama yang menjadi faktor utama penerimaan materi sejarah oleh siswa adalah faktor Siapa. Faktor ini merupakan rumusan dari beberapa jawaban responden yang beranggapan bahwa pada pembelajaran sejarah memang harus diajarkan oleh seseorang yang mengerti sejarah. Umumnya guru sejarah hanya sekedar menyampaikan beragam uraian fakta yang kering. Keadaan ini diperburuk dengan tampilnya guru yang mengajarkan sejarah tetapi tidak berlatar belakang pendidikan sejarah. Ini dapat terjadi karena adanya anggapan mengajar sejarah itu mudah karena hanya menyampaikan cerita yang ada di dalam buku teks (Suwandari, 2010) Oleh karena hal tersebut guru seharusnya mampu membawa siswa pada ranah pembelajaran yang menyenangkan. Aspek lain keberterimaan materi sejarah oleh siswa adalah bagaimana kemudian materi sejarah diajarkan, bagaimana materi sejarah diberikan kepada siswa. Perihal menyajikan materi sejarah kepada siswa menjadi sesuatu yang sangat penting karena menurut siswa hal tersebut sangat penting dalam menciptakan mood belajar.

Menurut Mulyana (2011) bahwa kepentingan penanaman nilai atau ideologi dan kepentingan kajian kritis dalam buku teks seharusnya dapat dipadukan. Ideologi atau nilai-nilai dapat tertanam dalam diri siswa ketika membaca buku teks pelajaran sejarah secara kritis, bukan penanaman ideologi atau nilai-nilai yang bersifat indoktrinasi. Dengan demikian buku teks dapat dipandang sebagai wacana yang merepresentasikan nilai-nilai dan ideologi tertentu. Nilai merupakan satu aspek yang menjadi fokus luaran dalam pembelajaran sejarah. Di samping itu, pelajaran sejarah juga mempunyai fungsi sosio-kultural, membangkitkan kesadaran historis. Sejarah nasional perlu menimbulkan kebanggaan nasional (national pride), harga diri, dan rasa swadaya. Menurut Aman, dengan demikian sangat jelas bahwa pelajaran sejarah tidak semata-mata memberi pengetahuan, fakta, dan kronologi. Dalam pelajaran sejarah perlu dimasukan biografi pahlawan mencakup soal kepribadian, perwatakan semangat berkorban, perlu ditanam historicalmindedness, perbedaan antara sejarah dan mitos, legenda, dan novel histories (Aman, 2009).

Pengembangan konten bahan ajar harus diarahkan pada peningkatan nilai-nilai yang positif. Kebaruan serta inovasi dalam pengembangan konten pembelajaran sejarah mutlak ada. Responden penelitian (siswa) berasumsi bahwa dalam memahami pembelajaran terdapat dua poin yang setidaknya harus menjadi acuan. Mudah dipahami dan tidak terlalu kompleks. Hal ini menjadi sebuah problematika yang harus dipecahkan. Menurut narasumber guru sejarah kelas XI di tempat penelitian, hal tersebut 
dikarenakan jumlah konten materi yang diajarkan cenderung tidak sesuai dengan jam pelajaran. Siswa tidak akan sepenuhnya membaca keselruhan materi, pada akhirnya siswa hanya harus memahami inti dari sebuah peristiwa maupun tokoh pahlawan sejarah.

Pengembangan konten kepahlawanan pembantu dalam hal pemahaman dasar diperlukan dalam menyokong pembelajaran sejarah di ruang-ruang kelas. Pada penelitian Aldila di tahun 2016 yang mengangkat mengenai pengembangan Infografis untuk meningkatkan hasil belajar, didapati sebuah fakta pada analisis kebutuhan dimana siswa selain ingin dapat memahami juga ingin mendapatkan kemudahan dalam memahami sebuah materi (Aldila, 2017). Beberapa permasalahan yang sering muncul siswa diberikan materi yang begitu kompleks namun tidak jarang guru tidak memberikan sebuah metode, cara ataupun trik dalam memahami materi tersebut sehingga memberikan kesulitan pada siswa. Menurut Musadad (2008) Kadar kualitas guru dipandang sebagai penyebab kualitas lulusan sekolah. Rendah dan merosotnya mutu pendidikan sebagaimana yang sering disinyalir oleh banyak media massa, hampir selalu disertai dengan menuding gurunya. Karena itu sangatlah disadari perlunya pembinaan profesional guru secara terarah dan terprogram untuk meningkatkan efektivitas mengajarnya. Termasuk dalam pengembangan bahan ajar bagi pembelajaran khususnya sejarah.

Menurut Jasson Lankow dalam bukunya Infografis: Kedahsyatan Cara Bercerita Visual, mengatakan keunggulan komunikasi visual melalui infografis antara lain: visualisasi gambar mampu menggantikan penjelasan yang terlalu panjang, serta menggantikan tabel yang rumit dan penuh angka. Melalui visualisasi grafis data yang menarik, pesanpesan kebijakan yang ingin disampaikan Bank Indonesia diharapkan lebih mudah mendapat perhatian dari publik (Lankow, 2015). Hal ini mengacu kepada beberapa hasil penelitian terdahulu yang menyebutkan bahwa mata manusia lebih cepat menangkap informasi yang tersaji dalam bentuk visual (grafis) daripada dalam bentuk tekstual, lalu kemudian cenderung menaruh atensi lebih besar untuk membaca isi pesan yang disampaikan.

Infografis merupakan satu media penyampai informasi yang mengedepankan aspek kreatif visual. Infografis telah dikenal pada dunia advertising dan pers. Penelitian (Taufik, 2012) menitiberatkan pada analisa mengenai penggunaan Infografik pada surat kabar Tempo guna keperluan jurnalistik. Berbeda dengan Taufik, (Arigia, 2016) ia meneliti mengenai kegunaan Infografis dalam penyampaian Informasi kepada masyarakat mengenai pemahaman dan keterlibatan publik Bank Indonesia. Kebijakankebijakan yang terdapat pada lembaga negara tersebut sungguh rumit sedangkan hal tersebut wajib diketahui masyarakat. Dari dua peneltian terdahulu yang dilaksanakan, keduanya belum sama sekali menyentuh bidang pendidikan. Kompleksitas materi pembelajaran merupakan hal yang sama dengan kompleksitas pada tulisan jurnalistik maupun kebijakan di Bank Indonesia seperti di atas. Dengan demikian infografis seharusnya juga menjadi salah satu desain aplikasi visual yang mampu diterima dan diterapkan oleh siswa maupun guru di sekolah. Taufik (2012) menjelaskan bahwa 
infografis bagian dari ilmu komunikasi visual, sebagai kajian dalam bentuk informasi grafis yang mana lebih banyak dipakai kebutuhan aplikasinya pada berbagai permasalahan dalam bidang kedokteran, dirgantara, ekonomi, sejarah, olahraga, politik dan seterusnya. Infografis banyak menjadi inspirasi untuk menjelaskan suatu data yang panjang menjadi bahasa penyampaian yang sangat pendek tapi sangat jelas.

Secara garis besar ada empat jenis infografis menurut Artacho (Artacho-Ramírez, 2008), yaitu :

1. Infografis yang berdasarkan pada statistik (statistical based) yaitu infografis yang berdasarkan pada statistik mencakup diagram, bagan, grafis, tabel dan daftar yang dapat meninjau informasi statistik.

2. Infografis yang berdasarkan pada jadwal (timeline based) yaitu infografis yang berdasarkan pada jadwal menunjukkan urutan kejadian dari waktu ke waktu dan juga memungkinkan audien memahami hubungan kronologis secara cepat. Tipe ini dapat ditunjukkan dalam bentuk tabel, paragraf tahun demi tahun, dan sebagainya.

3. Infografis yang berdasarkan pada proses (process based) atau dapat dipergunakan juga untuk menjelaskan tentang ruang kerja, pabrik atau kantor sehingga pembaca memahami ruang terbatas secara praktis.

4. Infografis yang berdasarkan pada lokasi atau geografi. Dengan mempergunakan geographic information system, peta dapat dipertimbangkan sebagai cara terbaik untuk menunjukan infografis berdasarkan geografi. Ada banyak notasi GIS yang dapat digunakan untuk mengidentifikasi jalan, kereta, tempat wisata, rumah sakit, bandara, dan sebagainya. Selain notasi, hal penting lainnya yang harus diperhatikan adalah penggunaan skala atau rasio yang tepat.

Bahan ajar yang didesain dengan bantuan unsur grafis memiliki nilai lebih. (Yusantiar, 2018) Warna adalah alat komunikasi tanpa bahasa dan bahasa untuk menyampaikan ide, gagasan, maupun pesan yang disampaikan. Selain warna, tipografi juga merupakan penciptaan suatu kesan dan kenyamanan membaca bagi audiens dengan cara memilih dan menata huruf yang sesuai pada suatu bidang dalam memilih tipografi yang benar harus memperhatikan keterbacaan, kejelasan, dapat dilihat, serta legibility (Wibowo, 2013). Perlu adanya sebuah inovasi dalam penyusunan bahan ajar pendamping buku paket yang merupakan suplemen dari buku pemerintah. Hal ini untuk memberikan beragam pilihan kepada peserta didik khususnya pada pembelajaran sejarah guna terciptanya minat belajar yang tinggi. Bahan ajar pengembangan juga mampu dijadikan rujukan tambahan bagi pembelajaran.

\section{METODE PENELITIAN}

Penelitian ini menggunakan metode pengembangan (Research and Development) untuk mencapai tujuan dan memecahkan masalah penelitian. Metode penelitian dan pengembangan (Research and Development) ialah metode penelitian yang digunakan untuk menghasilkan produk tertentu dan menguji keefektifan produk tersebut (Sugiyono, 2011). Pengembangan bahan ajar sejarah berbasis infografis mengikuti desain ADDIE. Langkah-langkahnya meliputi: analisis (Analyze), perancangan (Design), 
pengembangan (Development), implementasi (Implementation), dan evaluasi (Evaluation) (Heinich, 2002.).

Pengembangan dilakukan dengan menyusun bahan ajar sesuai dengan masukan reponden baik siswa maupun guru. Pada tahap setelahnya rancangan bahan ajar akan dilaksanakan validasi oleh validator/ekspert sebelum dilaksanakan diseminasi ataupun uji efektivitas pada langkah pengujian setelah pengembangan. Uji kecil dan besar dilaksanakan guna memperoleh masukan pada bahan ajar biografi pahlawan berbasis Infografis. Populasi dalam penelitian ini adalah Siswa kelas XI di SMAN 2 Ungaran, dan sampel yang diambil adalah kelas XI IPS 1 dan XI IPS 3. Pengumpulan data pada tahap analisis menggunakan metode wawancara dan observasi guna mendapatkan gambaran mengenai pembelajaran dan kondisi siswa serta bahan ajar. Pada tahap implementasi peneliti menggunakan metode tes guna mengukur hasil belajar dan kesadaran siswa. Tes dilakukan sebanyak dua kali yaitu di awal (pre test) dan di akhir pembelajaran (post test).

\section{HASIL DAN PEMBAHASAN}

\subsection{Data Lapangan}

Berdasarkan penyerapan data baik observasi maupun wawancara sebagai data pemandu awal pengembangan, terdapat beberapa fakta yang perlu dicermati dan menjadi acuan sebuah pengembangan bahan ajar. Belum terlaksananya pengembangan konten di tempat penelitian menjadi sebuah alasan kuat pertama untuk menyajikan sebuah kebaruan pengembangan. Konten pembelajaran di SMAN 2 Ungaran diperoleh dari download jejaring internet baik dari blog hingga youtube sebagai konten audio visual.

Fakta selanjutnya adalah siswa SMAN 2 Ungaran berpatokan pada dua aspek dalam memahami sebuah pembelajaran sejarah yaitu siapa dan bagaimana. Pada pembelajaran sejarah, peran guru menjadi sangat penting karena menurut pandangan para siswa ketika guru mampu membangun minat siswa untuk belajar sejarah tentu siswa akan termotivasi. Selanjutnya kapasitas guru juga mempengaruhi dalam keberterimaan pembelajaran pada siswa. Poin yang kedua adalah bagaimana kemudian konten sejarah disajikan kepada siswa. Siswa memiliki masalah dalam pemahaman materi sejarah yang cenderung panjang dan kompleks. Guru sejarah juga tidak memiliki banyak waktu dalam menyuruh siswa membaca komprehensif. Bagi siswa untuk memahami sejarah terlebih dahulu mereka harus paham konsep umumnya. Meski demikian siswa masih memilih buku sebagai sumber rujukan yang menurut mereka efisien sekalipun di tempat penelitian akses internet dan ponsel pintar diperbolehkan. Siswa juga beranggapan bahwa visualisasi dalam pembelajaran sejarah sangat perlu. Dengan adanya visualisasi dalam pembelajaran selain meningkatkan minat, mereka juga mampu merekam peristiwa maupun tokoh kedalam ingatan mereka untuk memancing pemahaman sejarah yang mereka pelajari sebelumnya.

Temuan lain dilapangan adalah siswa memiliki ketertarikan pada materi heroisme atau para tokoh pahlawan yang memiliki semangat untuk berjuang demi bangsa Indonesia. Namun demikian siswa belum mampu menyerap nilai-nilai apa yang diberikan pada tiap 
tokohnya. Mereka masih mengeneralisasi nilai dari setiap tokoh. Nilai sejarah (the value of history) merupakan studi tentang kehidupan manusia yang berhubungan dengan kemajuan dan peradaban (Pranoto, 2010).

Ketersediaan buku sejarah di tempat penelitian cukup memadai mencakup buku ajar hingga buku bacaan sejarah, tidak terkecuali mengenai biografi pahlawan. Namun demikian para siswa tidak memiliki banyak waktu untuk mengunjungi perpustakaan. Buku yang disediakan cenderung monoton dan full teks. Bagi sebagian siswa di satu kelas yang menjadi subjek penelitian mengatakan bahwa buku masih menjadi rujukan favorit mereka dalam pembelajaran. Namun mereka menganggap pada bagian materi yang kompleks, mereka sulit untuk menemukan inti materi yang dimaksud. Fokus yang ingin mereka dapatkan dalam pembelajaran sejarah adalah jelas, faham dan menyenangkan. Metode pembelajaran sejarah menurut Kasmadi (1996) berupa pemahaman gambar, belajar dengan peta, permainan drama dan simulasi, tugas menulis, studi dokumen, kajian teks, dan sebagainya. Metode pembelajaran sejarah yang dominan di berbagai jenjang pendidikan adalah ceramah dan dialog/diskusi, tugas individual, diskusi, dan visiting area.

Setelah didapati sebuah data mengenai keadaan siswa dan kebutuhan serta melihat dari hasil observasi mengenai bahan ajar yang digunakan di sekolah. Peneliti melakukan tahap selanjutnya dengan merancang bahan ajar dengan acuan pengembangan sebagai berikut: (1) Desain Produk, (2) Pengumpulan bahan, (3) Perancangan produk, (4) Validasi ahli, (5) Revisi desain, (6) Uji coba produk, dan (7) Hasil penelitian.

Pengembangan bahan ajar dilakukan dengan bantuan media konten infografis. Infografis adalah teknik menyajikan informasi secara visual/grafis, sehingga mudah dipahami oleh pembaca. Banyak orang salah mengartikan dengan menyebut kata infografik adalah karena pada infografis sering terlihat ada grafik (chart) apapun itu grafik batang atau pie chart. Padahal infografis sendiri masih sangat luas daripada hanya sekedar chart. Kemungkinan lainnya adalah orang menyebutkan kata infographic (dalam Bahasa Inggris) secara lisan, lalu terdengar sebagai infografik dalam Bahasa Indonesia (Saptodewo, 2014).

Penyusunan Infografis memiliki pola yang sama dengan pengembangan konten lainnya yaitu meliputi (1) penentuan ide, (2) menentukan konsep, (3) mengumpulkan data dan referensi, (4) menyusun layout desain, (5) Validasi (Aldila: 2016). Konten yang dikembangkan memilih infografis sebagai gaya penyajian data. Namun demikian dalam penilaian bahan ajar ini digunakan instrumen penilaian buku pengayaan dari Kementerian Pendidikan dan Kebudayaan Indonesia.

\subsection{Pengembangan Konten}

Bahan ajar sejarah biografi pahlawan dkembangkan dengan mengedepankan empat aspek konten sesuai dengan regulasi penilaian buku pengayaan dari Kemendikbud. Mengacu pada kebermaknaan konten, bahasa sesuai EYD, Penyajian dan Grafis. Adapun bagian- bagian dari bahan ajar yang telah dikembangkan adalah (1) Bahasan: bagian 
bahasan merupakan bagian materi mengenai peristiwa sejarah disampaikan dan disajikan. (2) Kolom tokoh: kolom tokoh berisi mengenai bahasan singkat mengenai tokoh-tokoh yang berperan maupun andil dalam peristiwa sejarah. (3) Timeline/garis waktu: bagian ini merupakan khas dari penembangan infografis yang mengedepankan aspek kronologi. Garis waktu untuk mempermudah dalam pemhaman aspek spasial sejarah oleh siswa. (4) Resume tokoh: pada bagian ini dapat ditemui pembahasan mengenai tokoh- tokoh pahlawan yang disusun berdasarkan dari tahun hidup hinggga tahun wafatnya beserta peran yang telah diambilnya.

Jika didasarkan pada Kompetensi dasar yang terdapat di SMAN 2 Ungaran, materi kepahlawanan terdapat pada kompetensi dasar menganalisis peran tokoh-tokoh nasional dan daerah dalam memperjuangkan kemerdekaan Indonesia dan menganalisis peran dan nilai-nilai perjuangan serta tokoh lainnya sekitar proklamasi. Kedua kompetensi dasar tersebut menjadikan acuan dalam pengembangan konten materi bahan ajar biografi pahlawan berbasis infografis. Berikut merupakan bagian bahan ajar biografi pahlawan berbasis infografis.

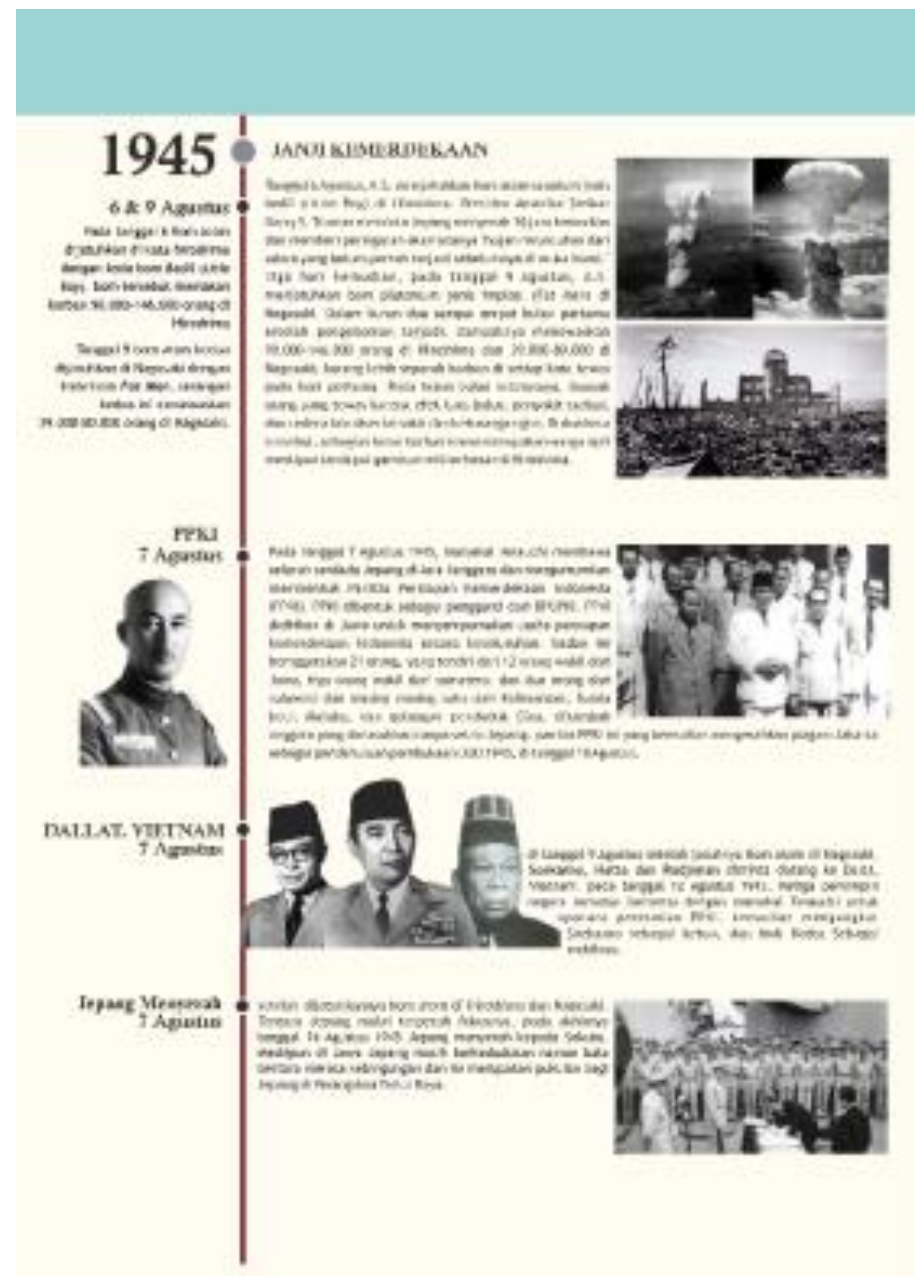

Gambar 1. Produk pengembangan bahan ajar biografi pahlawan masa Proklamasi bagian pembahasan dan rangkuman. 


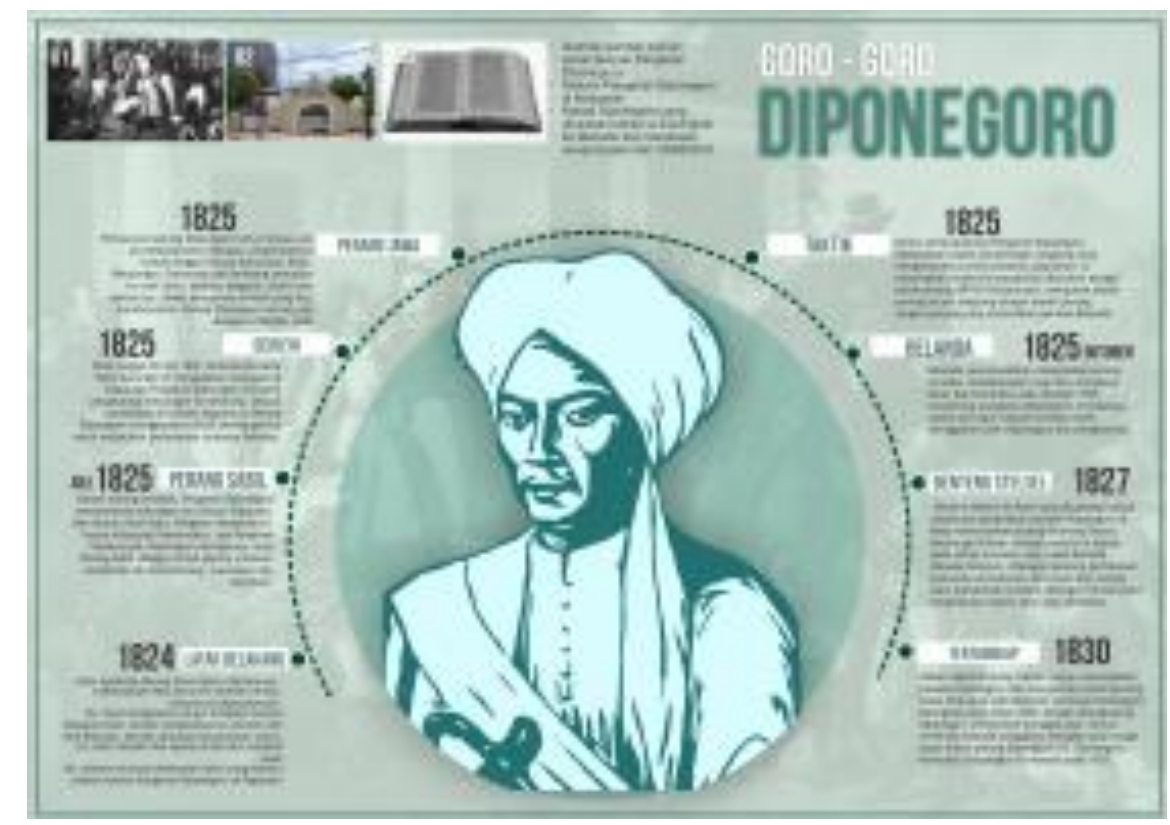

Gambar 2. Produk pengembangan bahan ajar biografi pahlawan Pangeran Diponegoro bagian pembahasan dan rangkuman.

Sebagai media untuk meningkatkan kemampuan analisis dan pemahaman siswa, bahan ajar ini juga dilengkapi dengan evaluasi singkat yang terletak dibagian belakang guna melihat kedalaman pemahaman siswa dengan menggunakan bahan ajar infografis.

\subsection{Validasi Ahli}

Sebelum dilaksanakannya uji coba produk dilapangan, bahan ajar terlebih dahulu harus mendapatkan validasi dari para ahli, baik dari ahli materi maupun ahli media pembelajaran. Validator dilakukan oleh 4 orang ahli, 2 orang dosen dan 2 orang guru. Berikut tabel rentang kelayakan bahan ajar.

Tabel 1. Rentang kelayakan bahan ajar

\begin{tabular}{|c|l|}
\hline Rentang persentase (\%) & \multicolumn{1}{|c|}{ Interpretasi } \\
\hline $81,5 \%<x \leq 100 \%$ & Sangat setuju / baik sekali \\
\hline $62,50 \%<x \leq 81,25 \%$ & Setuju / baik \\
\hline $43,75 \%<x \leq 62,50 \%$ & Ragu-ragu / tidak baik \\
\hline $25 \%<x \leq 43,75 \%$ & Tidak setuju / sangat tidak baik \\
\hline
\end{tabular}

Pada tahap pengembangan bahan ajar dilakukan validasi baik dari segi materi penyajian maupun dari segi media. Validasi tersebut dilaksanakan sebanyak dua tahap. Pada penilaian tahap I validasi materi menunjukkan nilai $82,9 \%$ dan materi $91,2 \%$. Pada tahap pertama bahan ajar telah dinyatakan sangat baik, namun demikian ada beberapa saran dan catatan perbaikan yang harus dilakukan baik dari segi materi maupun media. Setelah revisi tahap I dilaksanakan kemudian dilaksanakan validasi tahap II. Pada validasi 
tahap II dari segi materi menunjukan nilai 90,1\% dan media 91,1\%. Hasil validasi tahap II mendapat kriteria sangat baik, meskipun terdapat sedikit catatan namun bahan ajar telah dinyatakan Layak oleh ahli materi maupun media dan dapat digunakan untuk diterapkan dalam penelitian.

\subsection{Uji Kelayakan}

Uji coba produk juga dilaksanakan pada kelompok kecil dan kelompok besar. Sampel dari uji ini adalah kelas XI di SMAN 2 Ungaran. Uji kelompok kecil berjumlah 9 orang sedangkan uji kelompok besar terdapat 34 siswa. Berikut jabarannya.

Tabel 2. Hasil penilaian bahan ajar oleh siswa

\begin{tabular}{|c|c|c|c|c|c|c|c|c|}
\hline \multirow{2}{*}{ No } & \multirow{2}{*}{ Nama } & \multicolumn{4}{|c|}{ Aspek Penilaian } & \multirow{2}{*}{ Total } & \multirow{2}{*}{$\begin{array}{l}\text { Rata- } \\
\text { Rata } \\
\text { total }\end{array}$} & \multirow{2}{*}{ Keterangan } \\
\hline & & Materi & Penyajian & Bahasa & Grafis & & & \\
\hline 1 & $\begin{array}{l}\text { Afif Chandra } \\
\text { Kumara }\end{array}$ & 87 & 87 & 87 & 84 & 345 & \multirow{9}{*}{331.1} & \multirow{9}{*}{$\begin{array}{l}\text { Layak } \\
\text { dengan } \\
\text { predikat } \\
\text { Bagus }(* *)\end{array}$} \\
\hline 2 & Alda Amas & 81 & 81 & 80 & 86 & 328 & & \\
\hline 3 & $\begin{array}{l}\text { Annisa } \\
\text { Rahmadany }\end{array}$ & 87 & 81 & 86 & 84 & 338 & & \\
\hline 4 & $\begin{array}{l}\text { Alfian bhre } \\
\text { Wardhana }\end{array}$ & 84 & 82 & 85 & 86 & 337 & & \\
\hline 5 & $\begin{array}{l}\text { Ardan } \\
\text { Wibisono }\end{array}$ & 80 & 86 & 83 & 85 & 334 & & \\
\hline 6 & $\begin{array}{l}\text { Atikah sarah } \\
\text { Pulungan }\end{array}$ & 85 & 80 & 87 & 85 & 337 & & \\
\hline 7 & Bahrul Ulum & 80 & 82 & 87 & 81 & 330 & & \\
\hline 8 & $\begin{array}{l}\text { Citra Devi } \\
\text { Triana }\end{array}$ & 85 & 84 & 84 & 84 & 337 & & \\
\hline 9 & $\begin{array}{l}\text { Damar Indra } \\
\text { Jaya }\end{array}$ & 80 & 86 & 87 & 83 & 336 & & \\
\hline
\end{tabular}

Hasil uji coba draf pada siswa didapati nilai rerata 331,1. Nilai tersebut masuk dalam kategori Layak dengan predikat bagus atau pada taraf pembintangan dua $\left({ }^{* *}\right)$. Pada tahap uji kelayakan kelompok besar terdapat 34 siswa yang memberikan penilaian dengan jabaran sebagai berikut. Berdasarkam hasil uji coba kelompok besar didapati sebuah data seperti tertera di tabel. Rerata total yang dihasilkan adalah 332,4. Jika dianalisa menggunakan tabel penilaian buku pengayaan pengetahuan maka dapat diperoleh kesimpulan adalah Layak dengan predikat bagus dan mendapatkan pembintangan dua $\left({ }^{* *}\right)$. Saran dan masukan siswa merupakan bahan untuk acuan pembuatan draf final bahan ajar biografi pahlawan berbasis aplikasi infografis.

\section{KESIMPULAN}

Terdapat dua fokus yang perlu diperhatikan dalam pembelajaran sejarah. Aspek siapa dan bagamana sejarah diajarkan merupakan penentu minat belajar siswa di SMAN 2 Ungaran. Guru harus memiliki kemampuan dalam memberikan informasi dan 
pemahaman kepada siswa serta mampu membawa kelas pada suasana belajar yang menyenangkan. Setelahnya kemudian bagaimana materi sejarah akan diberikan. Siswa SMAN 2 Ungaran memiliki pandangan bahwa materi sejarah tidak mesti harus selalu memiliki bahasan yang kompleks, siswa hanya terkadang perlu memahami maksud dan inti dari peristiwa sejarah dan tokoh sejarah. Hal ini juga didasarkan data dari guru bahwa jam pelajaran sejarah teradang masih belum mencukupi jika dibandingkan dengan materi yang dberikan.

Melihat dari aspek pengembangan kondisi bahan ajar yang ada di SMAN 2 Ungaran belum pernah dikembangkan sebelumnya, hal ini dibuktikan dari hasil wawancara kepada guru SMAN 2 Ungaran. Kebutuhan akan bahan ajar dinilai sangat perlu dan dibutuhkan. Kompleksitas materi pada beberapa kompetensi dasar tertentu mengharuskan terciptanya media pembantu guna meningkatkan pemahaman dan juga minat siswa dalam pembelajaran. Visual dalam pembelajaran sejarah merupakan hal penting menurut pandangan dewan guru dan siswa. Hal ini dikarenakan mereka mampu memproyeksikan peristiwa sejarah dari gambaran visual.

Bahan ajar infografis mengacu pada perancangan infografis pada kontennya sedangkan penyajian/media pendukungnya mengacu pada regulasi buku pengayaan Kemendikbud. Begitupula dengan instrumen penilaiannya. Penyusunan infografis memiliki pola yang sama dengan pengembangan konten lainnya; (1) penentuan ide, (2) menentukan konsep, (3) mengumpulkan data dan referensi, (4) menyusun layout desain, (5) Validasi. Bahan ajar yang disusun oleh peneliti dinyatakan telah layak digunakan oleh para ahli baik ahli materi maupun media dibuktikan dengan validasi yang telah dilaksanakan sebanyak dua tahap dan keduanya memperoleh nilai kriteria sangat baik atau sangat layak digunakan untuk penelitian. Bahan ajar juga dinyatakan layak digunakan dalam pembelajaran setelah melalui pengujian kecil dan besar yang dilakukan oleh siswa sebagai penilai.

\section{DAFTAR PUSTAKA}

Adam, A. W. (2017). Pabrikasi Pahlawan Nasional : Revolusi tak Kunjung Selesai Potret Indonesia Masa Kini. Jakarta: KPG.

Aldila, T. h. (2017). Pengembangan Pembelajaran Sejarah Berbasis Infografis. Sejarah Indonesia : Cerdas dan Humanis di Era Digital (hal. 31 - 40). Yogyakarta: Sanata Dharma University Press.

Aman. (2009). Kesadaran Sejarah Dan Nasionalisme. INFORMASI.

Artacho-Ramírez, M Diego-Mas, J., \& Alcaide-Marzal, J. (2008). Influence of the mode of graphical representation on the perception of product aesthetic and emotional features: An exploratory study. International Journal of Industrial Ergonomics, 942-952.

B. U. Dur. (2014). Data Visualization and Infographics in the Visual Communication Design Education. Journal of Art and Humanity.

Heinich, R. M. ( 2002.). Instructional media and technology for learning, 7th edition. New Jersey:: Prentice Hall, Inc. 
Kasmadi, H. (1996). Model - mode dalam Pengajaran Sejarah. Semarang: IKIP Semarang Press.

Kim, T. \&. (2010). Speculative Visualization: A New Rhetoric for Communicating Public. Design Research Society International Conference Design \& Complexity. Montreal: DRS Conference Proceedings.

Krum, R. (2013). Cool Infographics: Effective Communication with Data Visualization and Design . Indiana: John Wiley \& Sons, Inc. .

Lankow, J. (2015). Infografis: Kedahsyatan cara bercerita Visual . -: Gramedia Pustaka Utama.

McLuhan, M. (1996). The Medium is The Message: An Inventory. San Francisco: Hardwire.

Muhammad Bintang Arigia, T. D. (2016). Infografis Sebagai Media Dalam Meningkatkan Pemahaman Dan. Jurnal Komunikasi, 120-133.

Mulyana, A. (2011). http://berita.upi.edu. Diambil kembali dari www.upi.edu: http://berita.upi.edu/2011/07/26/historiografi-buku-teks-pelajarandisekolah/

Musadad, A. A. (2008). Optimalisasi Pembinaan Guru Baru dalam Pembelajaran Sejarah. PAEDAGOGIA, , 51 - 61. .

Pranoto, S. (2010). Teori dan Metodologi Sejarah. Jakarta : Graha Ilmu.

Prastowo, A. (2015). PANDUAN KREATIF MEMBUAT BAHAN AJAR INOVATIF. JOGJAKARTA: Diva Press.

Purwanto., B. (2006). Gagalnya Historiografi Indonesiasentris. Yogyakarta: Ombak.

Saptodewo, F. (2014). Desain Infografis Sebagai Penyajian Data Menarik. JURNAL DESAIN, 163-2118.

Sugiyono. (2011). Metode Penelitian Kuantitatif, Kualitatif dan R\&D. Bandung: Alfabeta.

Sugoyono. (2015). Metode Penelitian Uantitatif, Kualitatif dan R\&D. BANDUNG: ALFABETA.

Suwandari. (2010). Paradigma Pendidikan Sejarah dalam Tantangan Menghadapi Masa Depan. Cakrawala Pendidikan, 27 - 43.

Syamsuddin, H. (1998). Penulisan Buku Teks Sejarah : Kriteria dan Permasalahannya. Simposium Pengajaran Sejarah. Jakarta: Depdikbud RI.

Taufik, M. (2012). Infografis Sebagai Bahasa Visual Pada Surat Kaar Tempo. Techno CQM, 156-163.

Wawan Darmawan, Agus Mulyana. (2016). Antara Sejarah dan Pendidikan : Analisis Terhadap Buku Teks Pelajaran Sejarah SMA Berdasarkan Kurikulum 2013. Penelitian Hibah Penguatan Kompetensi UPI.

Westomi, J. A. (2018). Pengembangan Paket Modul Cetak Mata Pelajaran Pendidikan Agama Islam untuk Siswa SMA Neger 1 Wangi - Wangi Kabupaten Wakatobi. Jurnal Teknologi Pendidikan.

Wibowo, I. T. (2013). Belajar Desain Grafis. Yogyakarta: Buku Pintar.

Wiraatmadja, R. (2002). Pendidikan Sejarah di Indonesia : Perspektif Nasional dan Global. Bandung: Bandung Historia tama Press.

Yusantiar, R. (2018). Perancangan Identitas Visual untuk Promosi Pariwisata Kabupaten Rembang . Andharupa, 201 - 220. 